The Castle Lectures in Ethics, Politics, and Economics 



\section{How Democratic}

Is the American Constitution? S E C OND E D I T ION

\section{Robert A. Dahl}

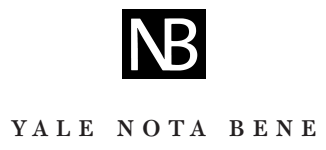

Yale University Press / New Haven \& London 
Published with assistance from the foundation established in memory of Philip Hamilton McMillan of the Class of 1894, Yale College.

This Nota Bene edition published 2003 by Yale University Press.

First Edition published 2002 by Yale University Press.

Second Edition copyright (C) 2003 by Yale University.

First Edition copyright (C) 2002 by Yale University.

All rights reserved.

This book may not be reproduced, in whole or in part, including illustrations, in any form (beyond that copying permitted by Sections 107 and 108 of the U.S. Copyright Law and except by reviewers for the public press), without written permission from the publishers.

Designed by James J. Johnson and set in New Caledonia and Bulmer types by Integrated Publishing Solutions.

Printed in the United States of America.

For information about this and other Yale University Press publications, please contact:

U.S. office_sales.press@yale.edu

Europe office sales@yaleup.co.uk

Library of Congress Control Number: 2003106483

ISBN 0-300-09524-4 (pbk)

A catalogue record for this book is available from the British Library.

109876654321 
Parts of this book were given as a series of Castle Lectures in Yale's Program in Ethics, Politics, and Economics, delivered by Robert Dahl at Yale University in 2000 .

The Castle Lectures, endowed by Mr. John K. Castle, honor his ancestor, the Reverend James Pierpont, one of Yale's founders. Given by prominent public figures, the lectures are intended to promote reflection on the moral foundations of society and government and to enhance understanding of ethical issues facing individuals in our complex modern society. 
